\title{
Greenhouse gas production in low-latitude lake sediments responds strongly to warming
}

\author{
H. Marotta, L. Pinho, C. Gudasz, David Bastviken, L.J. Tranvik and Alex Enrich Prast
}

\section{Linköping University Post Print}

\section{Tweet}

N.B.: When citing this work, cite the original article.

Original Publication:

H. Marotta, L. Pinho, C. Gudasz, David Bastviken, L.J. Tranvik and Alex Enrich Prast, Greenhouse gas production in low-latitude lake sediments responds strongly to warming, 2014, Nature Climate Change, (4), 6, 467-470.

http://dx.doi.org/10.1038/NCLIMATE2222

Copyright: Nature Publishing Group

http://www.nature.com/

Postprint available at: Linköping University Electronic Press

http://urn.kb.se/resolve?urn=urn:nbn:se:liu:diva-108800 


\title{
Greenhouse gas production in low latitude lake sediments responds strongly to warming
}

\author{
Marotta, H.1,2 Pinho, L. ${ }^{3}$ Q., Gudasz, C.4,5, Bastviken, D. 6, Tranvik, L. J.4 \& Enrich-Prast, A.2,3 \\ 1 Sedimentary and Environmental Processes Laboratory (LAPSA/UFF), Department of Geography, \\ Institute of Geosciences, Universidade Federal Fluminense, 24210-346 Niterói, Brazil. \\ 2 International Laboratory of Climatic Change (LINCGlobal), Universidade Federal do Rio de Janeiro, \\ 68020 Rio de Janeiro, Brazil.
}

3 Laboratory of Biogeochemistry, Department of Ecology, Institute of Biology, Universidade Federal do Rio de Janeiro, 68020 Rio de Janeiro, Brazil.

${ }^{4}$ Department of Ecology and Genetics, Limnology, Uppsala University, 75236 Uppsala, Sweden.

5 Department of Ecology and Evolutionary Biology, Princeton University, Princeton, NJ 08544-2016 U.S.A.

${ }^{6}$ Department of Thematic Studies - Water and Environmental Studies, Linköping University, 58183 Linkoping, Sweden.

\begin{abstract}
Inland water sediments receive large quantities of terrestrial organic matter ${ }^{1-5}$ and are globally important sites for organic carbon preservation ${ }^{5-6}$. Sediment organic matter mineralization is positively related with temperature across a wide range of high-latitude ecosystems ${ }^{6-10}$, but the situation in the tropics remains unclear. Here we assessed temperature effects on the biological production of $\mathrm{CO}_{2}$ and $\mathrm{CH}_{4}$ in anaerobic sediments of tropical lakes in the Amazon and boreal lakes in Sweden. Based on conservative regional warming projections until 210011, we estimate that sediment $\mathrm{CO}_{2}$ and $\mathrm{CH}_{4}$ production will increase 9-61 \% above present rates. Combining the $\mathrm{CO}_{2}$ and $\mathrm{CH}_{4}$ as $\mathrm{CO}_{2}$ equivalents $\left(\mathrm{CO}_{2 \mathrm{eq}}\right)^{11}$, the predicted increase is $2.4-4.5$ times higher in tropical than boreal sediments. Although the estimated lake area in low latitudes is 3.2 times smaller than that of the boreal zone, we estimate that the increase in gas production from tropical lake sediments would be on an average 2.4 times higher for $\mathrm{CO}_{2}$ and 2.8 times higher for $\mathrm{CH}_{4}$. The exponential temperature response of organic matter mineralization, coupled with higher increases in the proportion of $\mathrm{CH}_{4}$ relative to $\mathrm{CO}_{2}$ upon warming, suggests that the production of GHGs in tropical sediments will increase substantially. This represents a potential large-scale positive feedback to climate change.
\end{abstract}




\section{Main text}

Tropical and boreal biomes harbour approximately $50 \%$ of the lakes on Earth ${ }^{12}$. These inland waters emit substantial amounts of carbon dioxide $\left(\mathrm{CO}_{2} \text {; in the order of } 0.5 \mathrm{Pg} \mathrm{yr}^{-1}\right)^{1,4,13,14}$ and methane $\left(\mathrm{CH}_{4} ; 70 \mathrm{Tg} \mathrm{yr}^{-1}\right)^{15}$. Organic matter escapes mineralization via burial in lake sediments, representing a global carbon (C) sink $\mathrm{k}^{13-15}$. Cold conditions are favouring organic carbon (OC) preservation in lakes at northern latitudes ${ }^{8-10,16}$, whereas warm inland waters show intense organic degradation supporting high C emissions to the atmosphere ${ }^{4,5,17,18}$.

Temperature and OC mineralization were recently shown to be strongly positively related in boreal lake sediments overlain by oxic water ${ }^{9}$. However, the majority of freshwater sediments below the uppermost layer (typically a few $\mathrm{mm}$ ) are anoxic ${ }^{19}$, where the anaerobic biological degradation of OC releases not only $\mathrm{CO}_{2}$ but also significant amounts of $\mathrm{CH}_{4}{ }^{15}$. Although higher temperatures are also expected to increase metabolic responses ${ }^{20}$, the effects of changing temperatures on OC mineralization can depend on several factors including organic matter characteristics (e.g. the Carbon-QualityTemperature hypothesis) ${ }^{21}$. Thus, the temperature sensitivity of OC stocks at high latitudes previously reported 6-8,16, may not be valid in the tropics where temperature sensitivity data is much more scarce ${ }^{22}$. We compared the anaerobic OC mineralization to $\mathrm{CO}_{2}$ and $\mathrm{CH}_{4}$ in tropical and boreal lake sediments along a temperature gradient. We simultaneously sampled a wide range of lake sediments from both tropical and boreal zones (see Supplementary Information, SI, Table S1). We assessed the temperature response of $\mathrm{OC}$ mineralization to $\mathrm{CO}_{2}$ and $\mathrm{CH}_{4}$ in the different sediments in one integrated experiment to ensure that all sediments were treated similarly. The temperature range used for all sediments in the experiment was $4-40^{\circ} \mathrm{C}$, and the results were compared with expected temperature increases according to the conservative B1 IPCC scenario ${ }^{11}$ (see SI for details).

Anaerobic OC mineralization increased exponentially with temperature (Figure 1) (i.e., linear regressions of $\log _{10} \mathrm{C}$ gas production versus temperature; see SI and Table 1 for further details). The temperature sensitivity of the anaerobic OC mineralization was not significantly different between boreal and tropical lakes based on Wilcoxon rank-sum test for $\mathrm{CH}_{4}(\mathrm{~W}=30, P=0.61), \mathrm{CO}_{2}(\mathrm{~W}=37, P=$ $0.96)$ and $\mathrm{CO}_{2 \text { eq }}(W=41, P=0.67)$. This was confirmed using alternative statistical approaches including a t-test and one-way ANOVA (p-values were always $>0.3$ for both slopes and intercepts in the tropical and boreal equations given in Table 1). The temperature sensitivity varied among lakes (Figures S1 and S2), but was on average not different between biomes.

Based on the slopes and intercepts reported in Table 1 and current annual average temperatures at the sediment surface of $4^{\circ} \mathrm{C}$ for boreal and $26^{\circ} \mathrm{C}$ for tropical sediments (see SI for details), the anaerobic OC mineralization would be 4.9-fold higher in tropical than in boreal sediments (expressed in $\mathrm{CO}_{2}$ equivalent units to account for both $\mathrm{CO}_{2}$ and $\mathrm{CH}_{4} ; \mathrm{mg} \mathrm{CO}_{2 \mathrm{eq}} \mathrm{L}_{\text {wet sediment }}{ }^{-1} \mathrm{yr}^{-1}$ ). Because anaerobic sediment mineralization dominates in most of the sediment volume, and because a similar exponential temperature dependence of OC mineralization of sediments overlain by oxic water has been found previously ${ }^{9}$, the temperature sensitivity might be representative for overall sediment mineralization. This study addresses the temperature sensitivity of $\mathrm{CO}_{2}$ and $\mathrm{CH}_{4}$ gas production rates rather than fluxes to the atmosphere. Not all the produced gas will reach the atmosphere, but the sediment production rates determine the potential for subsequent atmospheric emissions and climate feedbacks.

To estimate the relative effect of global warming over this century on anaerobic $\mathrm{OC}$ mineralization in boreal and tropical lake sediments, we used the temperature-sediment mineralization relationships in Table 1, the current temperatures, and the projected temperature at the end of the century according to the IPCC B1 scenario ${ }^{11}$ (see SI). Under this scenario, the temperature response observed in this study was extrapolated to the estimated lake area fraction being shallow enough for transfer of atmospheric temperature increase to the sediment (see SI for details). Relative to present levels, $\mathrm{CO}_{2}, \mathrm{CH}_{4}$ and $\mathrm{CO}_{2 \mathrm{eq}}$ production rates across lakes is estimated to increase by 9-31, 20-61, and 14-40\%, respectively (Table 2). However, in absolute terms, the increase is expected to be significantly higher in sediments of tropical lakes, as compared to boreal lakes. We find that the $\mathrm{CO}_{2}$ and $\mathrm{CH}_{4}$ production would increase at least 2.4-2.5 and 2.8-2.9 times more in tropical compared with boreal sediments, reaching a 3.0-3.2 fold higher increase in combined $\mathrm{CO}_{2}$ and $\mathrm{CH}_{4}$ production as $\mathrm{CO}_{2 \mathrm{eq}}$ in tropical sediments. This result is robust to variability between lakes. When repeating the extrapolation using all combinations of the $25 \%$ and 
$75 \%$ quartiles of slopes and intercepts in the temperature responses for specific lakes (se $\mathrm{SI}$ ), the $\mathrm{CO}_{2 \mathrm{eq}}$ production increase in tropical sediments is 2.4-4.5 times higher than in boreal sediments.

a

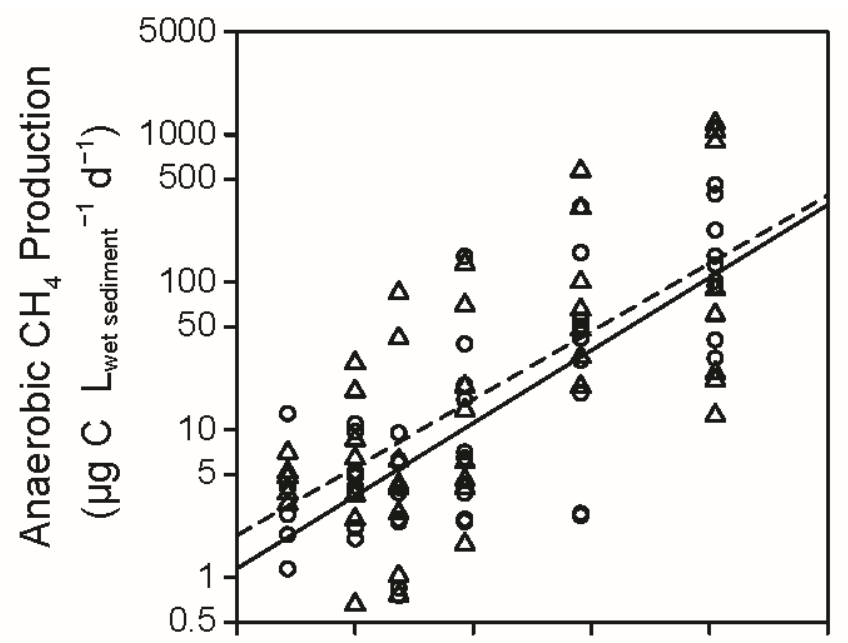

b

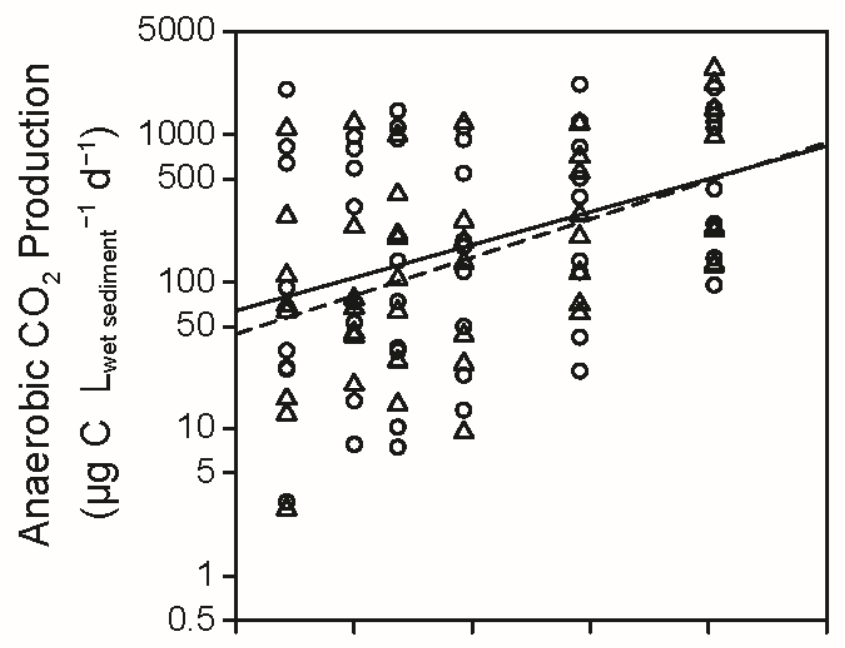

C

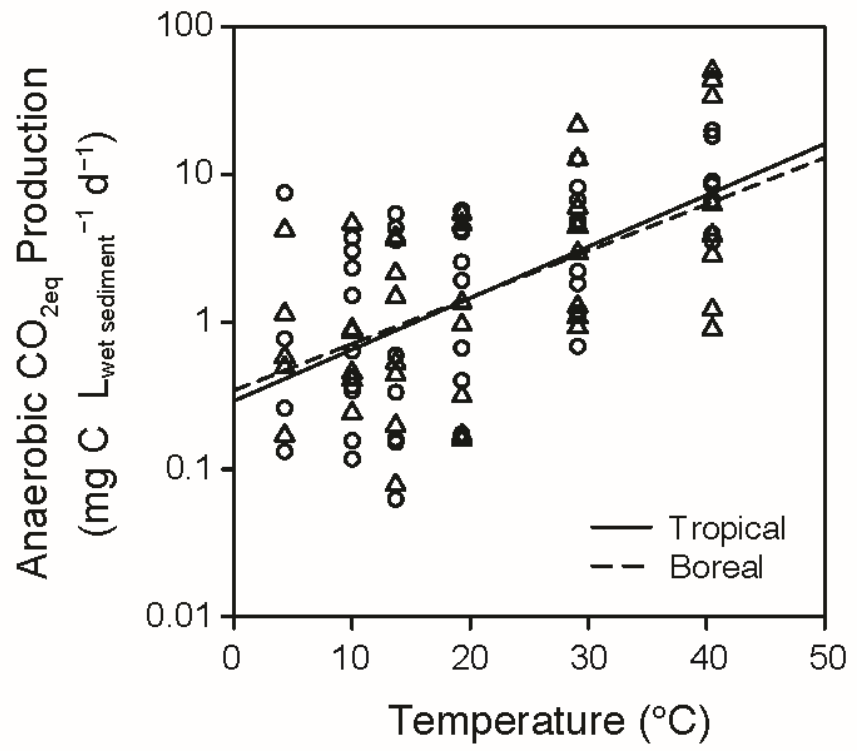

Figure 1: Temperature sensitivity of anaerobic $\mathrm{CO}_{2}$ and $\mathrm{CH}_{4}$ production in lake sediments. (a) $\mathrm{CH}_{4}$, (b) $\mathrm{CO}_{2}$, and (c) $\mathrm{CO}_{2}$ equivalent ( $\mathrm{CO}_{2 \text { eq }}$ ) production for tropical (open circles) and boreal (triangles) sediments. Solid and dashed lines represent the fitted regressions $(\mathrm{p}<0.05)$ for tropical and boreal lake sediments (see Table 1 for regression parameters). Note that units for $\mathrm{CO}_{2}$ and $\mathrm{CH}_{4}$ (mass of $\mathrm{C}$ ) differ from $\mathrm{CO}_{2}$ eq units (mass of $\mathrm{CO}_{2}$ molecules). 


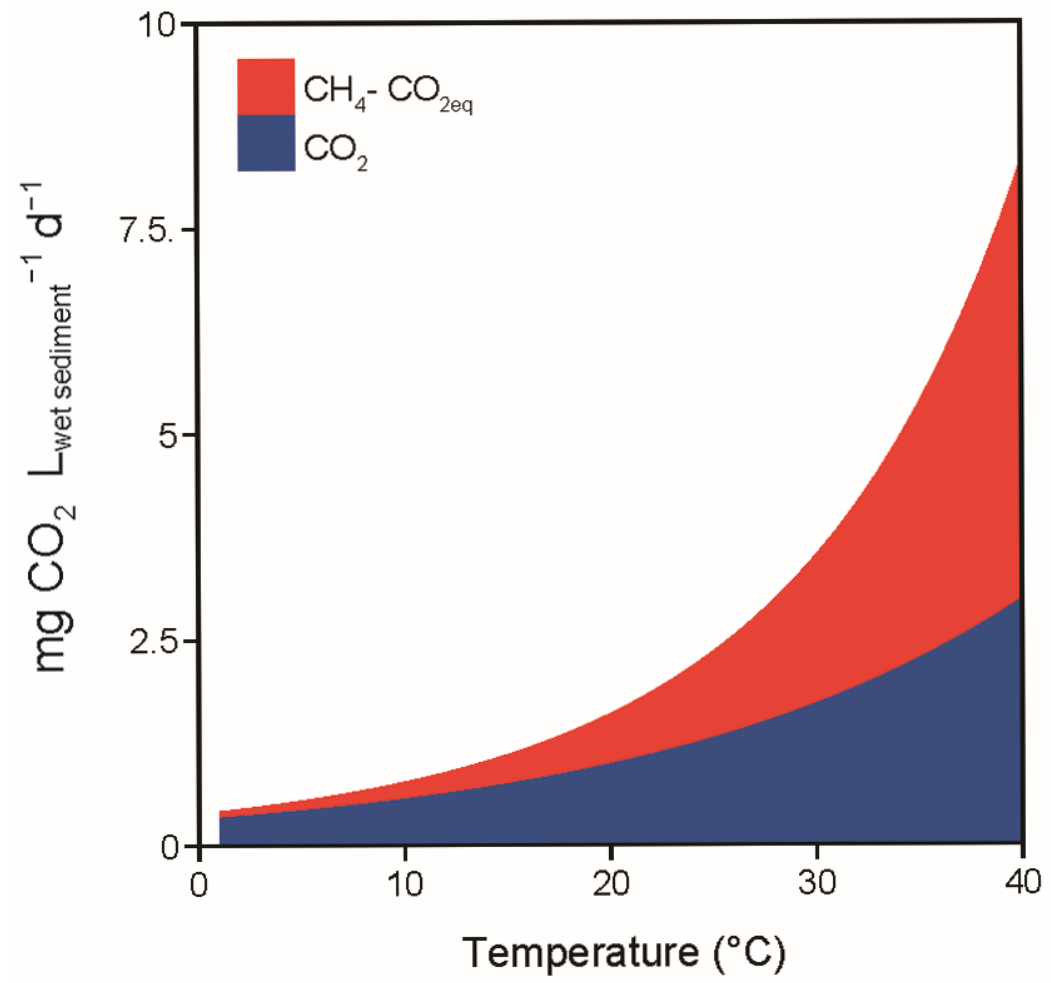

Figure 2: Contribution of $\mathrm{CO}_{2}$ and $\mathrm{CH}_{4}$ to total $\mathrm{CO}_{2}$ eq production at different temperatures. The model is based on the temperature response equations using both tropical and boreal data in Table 1.

The stronger temperature response of $\mathrm{CH}_{4}$ production relative to $\mathrm{CO}_{2}$, and being evident at tropical temperatures, suggests a more powerful positive feedback on global warming than indicated by the $\mathrm{CO}_{2}$ production alone (Figure 2). One possible explanation for this is that $\mathrm{CH}_{4}$ is increasingly produced from $\mathrm{CO}_{2}$ and $\mathrm{H}_{2}$ rather than from acetate at increasing temperatures, resulting in $\mathrm{CO}_{2}$ consumption by methanogenesis under warmer conditions ${ }^{23,24}$. The larger effect of warming in the tropics corresponds

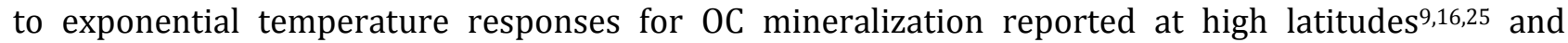
highlights that small temperature changes in warm environments can result in greater effects than larger temperature changes in cold areas.

The difference in the tropical versus boreal temperature response is likely underestimated here for two reasons. First, the global tropical inundated area may be substantially larger than we assume ${ }^{4}$. Accordingly, a detailed survey of the average flooded area in the lowland Amazon alone, including lakes, rivers and wetlands ${ }^{26}$, reports an area substantially larger than the global tropical area used here. Second, we assumed a $4^{\circ} \mathrm{C}$ average present boreal temperature at the sediment surface, in spite of average air temperatures of between -5 to $+5{ }^{\circ} \mathrm{C}$ over the boreal zone ${ }^{27}$, and without considering the near- or sub-zero temperatures under ice during winter in epilimnetic boreal sediments. All these known uncertainties regarding areal estimates and present boreal sediment temperatures suggest that the difference in warming feedback between tropical and boreal sediment mineralization reported here is conservative. 
Table 1. Slopes (S) and intercepts (I) in the temperature response equations, the standard errors (SE) or S and I, and tests of differences between biomes for these parameters. The general equation format is $\log _{10}(\mathrm{~F})=\mathrm{S} * \mathrm{~T}+\mathrm{I}$, where $\mathrm{F}$ is the formation rate of $\mathrm{CH}_{4}, \mathrm{CO}_{2}$, (both as $\mu \mathrm{g} \mathrm{C} \mathrm{L}$ wet sediment ${ }^{-1} \mathrm{~d}^{-1}$ ), or $\mathrm{CO}_{2}$ equivalents $\left(\mathrm{mg} \mathrm{CO}_{2} \mathrm{~L}_{\text {wet sediment }}{ }^{-1}\right.$ $\mathrm{d}^{-1}$; note different units) and $\mathrm{T}$ is temperature in ${ }^{\circ} \mathrm{C}$.

\begin{tabular}{|c|c|c|c|c|c|c|c|c|}
\hline & Biome $^{a}$ & $S$ & $\begin{array}{c}\text { SE } \\
\text { of } S\end{array}$ & $I$ & $\begin{array}{c}\text { SE } \\
\text { of } I\end{array}$ & $\mathbf{R}^{2}$ & p-value & $\mathbf{n}$ \\
\hline \multirow[t]{3}{*}{$\mathrm{CH}_{4}$} & Tropical & 0.049 & 0.006 & 0.060 & 0.14 & 0.59 & $<0.001$ & 48 \\
\hline & Boreal & 0.046 & 0.008 & 0.28 & 0.19 & 0.44 & $<0.001$ & 44 \\
\hline & All data & 0.047 & 0.005 & 0.17 & 0.11 & 0.51 & $<0.001$ & 94 \\
\hline \multirow[t]{3}{*}{$\mathrm{CO}_{2}$} & Tropical & 0.022 & 0.008 & 1.81 & 0.19 & 0.11 & 0.009 & 53 \\
\hline & Boreal & 0.026 & 0.007 & 1.65 & 0.17 & 0.11 & 0.009 & 46 \\
\hline & All data & 0.024 & 0.005 & 1.73 & 0.13 & 0.16 & $<0.001$ & 99 \\
\hline \multirow{3}{*}{$\begin{array}{l}\mathrm{CO}_{2} \\
\text { equivalents }\end{array}$} & Tropical & 0.035 & 0.007 & -0.54 & 0.16 & 0.36 & $<0.001$ & 49 \\
\hline & Boreal & 0.032 & 0.007 & -0.47 & 0.18 & 0.30 & $<0.001$ & 42 \\
\hline & All data & 0.033 & 0.004 & -0.50 & 0.11 & 0.34 & 0.001 & 91 \\
\hline
\end{tabular}

a At the population level, slopes and intercepts for tropical and boreal regressions were not significantly different (see text for details). Therefore a general equation based on both tropical and boreal data was made.

Table 2: The predicted increase in anaerobic sediment production of $\mathrm{CO}_{2}, \mathrm{CH}_{4}$ and $\mathrm{CO}_{2}$ eq, relative to the current conditions, following a temperature change according to the IPCC B1 warming scenario projected for the year 2100. See SI for calculation details.

\begin{tabular}{lccc}
\hline $\begin{array}{l}\text { Sediment } \\
\text { source }\end{array}$ & $\mathrm{CO}_{2}$ & $\mathbf{C H}_{\mathbf{4}}$ & $\mathbf{C O}_{2 \mathbf{e q}}$ \\
& $\mathbf{( \% )}$ & $\mathbf{( \% )}$ & $\mathbf{( \% )}$ \\
\hline Tropical lakes & $9-24$ & $20-58$ & $14-40$ \\
Boreal lakes & $11-31$ & $21-61$ & $14-39$ \\
\hline
\end{tabular}

Nevertheless, under warming scenarios with a lower predicted absolute temperature increase in the tropics than in northern ecosystems ${ }^{11}$, we show that the total OC mineralization, and the proportion of mineralization that is channelled into $\mathrm{CH}_{4}$ production, will most likely increase more in low- than in high-latitude lake sediments. Flooded areas in the warm tropics, including lakes and wetlands, are extensive sites for OC decomposition and GHG emissions to the atmosphere ${ }^{4,18}$, which may even show hypoxia events in bottom waters near to the sediment ${ }^{29}$. Thus, these stocks of OC may be particularly sensitive to small increases in temperature, thereby contributing to a potentially important positive feedback on global warming. 


\section{Methods summary}

A 10-cm surface layer of the sediment was sampled in Amazonian tropical and Swedish boreal lakes ( $n=9$ and 8, respectively), encompassing a typical range of ecosystem types (see SI for details). The experiments for both biomes were performed simultaneously in Sweden and were initiated within 9 days of sampling. Anoxic sediment slurries with a nitrogen gas headspace were incubated in 2516 hermetically sealed $25-\mathrm{ml}$ glass vials capped with $10-\mathrm{mm}$ massive butyl rubber stoppers and maintained at six controlled temperatures $\left(4.3,10,13.7,19.3,29.1,40.5^{\circ} \mathrm{C}\right)$ in the dark and inside boxes filled with water. After $0,3,6,10,20,30$ and 44 days of incubation, the vials $(n=4$ for each temperature and lake) were removed and biological activity stopped by acidification to $\mathrm{pH}<1.5$. The headspace was then sampled, and the gas was analysed for $\mathrm{CO}_{2}$ and $\mathrm{CH}_{4}$ concentrations using a 6890 Agilent gas chromatograph (Agilent Technologies) equipped with TCD and FID detectors and a nickel catalyst methanizer. Production rates were determined from the maximum significantly linear slope of the $\mathrm{CO}_{2}$ and $\mathrm{CH}_{4}$ concentrations for at least 3 consecutive samplings over 44 days. Because of the acid preservation, $\mathrm{CO}_{2}$ accumulation corresponds to formation of all inorganic carbon in the vials. Anaerobic OC mineralization expressed as $\mathrm{CO}_{2}$ equivalents $\left(\mathrm{CO}_{2 \text { eq }}\right)$ was calculated as the sum of the concentration of both $\mathrm{CO}_{2}$ and $\mathrm{CH}_{4}$ (in mass units) assuming a 25 -fold greater radiative forcing for $\mathrm{CH}_{4}{ }^{11}$. Production rates as $\mathrm{CO}_{2}$ eq were then calculated as described for $\mathrm{CO}_{2}$ and $\mathrm{CH}_{4}$. The slope of the linear fit of $\log _{10^{-}}$ transformed production rates vs. temperature was used as a measure of temperature sensitivity. The slopes of the above linear regression analyses, representing the temperature sensitivity of anaerobic OC mineralization from tropical and boreal lakes was compared using parallel approaches including Wilcoxon rank-sum test, t-test and one-way ANOVA (significance $\mathrm{p}<0.05$ ). The data were analysed using $\mathrm{R}$ software ${ }^{28}$. For full details regarding the lakes, experimental design, analytical methods, calculations and statistics, see SI. 


\section{References}

1 Cole, J. J., Caraco, N. F., Kling, G. W. \& Kratz, T. K. Carbon-dioxide supersaturation in the surface waters of lakes. Science 265, 1568-1570, (1994).

2 Cole, J. J. et al. Plumbing the global carbon cycle: Integrating inland waters into the terrestrial carbon budget. Ecosystems 10, 171-184 (2007).

3 Duarte, C. M. \& Prairie, Y. T. Prevalence of heterotrophy and atmospheric $\mathrm{CO}_{2}$ emissions from aquatic ecosystems. Ecosystems 8, 862-870 (2005).

4 Marotta, H., Duarte, C. M., Sobek, S. \& Enrich-Prast, A. Large $\mathrm{CO}_{2}$ disequilibria in tropical lakes. Global Biogeochemical Cycles 23 (2009).

5 Downing, J. A. et al. Sediment organic carbon burial in agriculturally eutrophic impoundments over the last century. Global Biogeochemical Cycles 22 (2008).

6 Kortelainen, P., Pajunen, H., Rantakari, M. \& Saarnisto, M. A large carbon pool and small sink in boreal Holocene lake sediments. Glob. Change Biol. 10, 1648-1653, (2004).

7 Zimov, S. A., Schuur, E. A. G. \& Chapin, F. S. Permafrost and the global carbon budget. Science 312, 1612-1613 (2006).

8 Walter, K. M., Zimov, S. A., Chanton, J. P., Verbyla, D. \& Chapin, F. S. Methane bubbling from Siberian thaw lakes as a positive feedback to climate warming. Nature 443, 71-75 (2006).

9 Gudasz, C. et al. Temperature-controlled organic carbon mineralization in lake sediments. Nature 466, 478-483 (2010).

10 Bergström, I., Kortelainen, P., Sarvala, J. \& Salonen, K. Effects of temperature and sediment properties on benthic $\mathrm{CO} 2$ production in an oligotrophic boreal lake. Freshwater Biology 55, 17471757 (2010).

11 Solomon, S. et al. Contribution of Working Group I to the Fourth Assessment Report of the Intergovernmental Panel on Climate Change. (Cambridge University Press, Cambridge, United Kingdom, 2007).

12 Lehner, B. \& Doll, P. Development and validation of a global database of lakes, reservoirs and wetlands. J. Hydrol. 296, 1-22 (2004).

13 Molot, L. A. \& Dillon, P. J. Storage of terrestrial carbon in boreal lake sediments and evasion to the atmosphere. Global Biogeochemical Cycles 10, 483-492 (1996).

14 Tranvik, L. J. et al. Lakes and reservoirs as regulators of carbon cycling and climate. Limnol. Oceanogr. 54, 2298-2314 (2009).

15 Bastviken, D., Tranvik, L. J., Downing, J. A., Crill, P. M. \& Enrich-Prast, A. Freshwater methane emissions offset the continental carbon sink. Science 331 (2011).

16 Benoy, G., Cash, K., McCauley, E. \& Wrona, F. Carbon dynamics in lakes of the boreal forest under a changing climate. Environ. Rev. 15, 175-189 (2007).

17 Marotta, H., Duarte, C. M., Pinho, L. \& Enrich-Prast, A. Rainfall leads to increased $\mathrm{pCO}_{2}$ in Brazilian coastal lakes. Biogeosciences 7, 1607-1614 (2010).

18 Bastviken, D. et al. Methane Emissions from Pantanal, South America, during the Low Water Season: Toward More Comprehensive Sampling. Environ. Sci. Technol. 44, 5450-5455 (2010).

19 Sobek, S. et al. Organic carbon burial efficiency in lake sediments controlled by oxygen exposure time and sediment source. Limnol. Oceanogr. 54, 2243-2254 (2009).

20 Dillon, M. E., Wang, G. \& Huey, R. B. Global metabolic impacts of recent climate warming. Nature 467, 704-706 (2010).

21 Bosatta, E. \& Ågren, G. I. Soil organic matter quality interpreted thermodynamically. Soil Biol. Biochem. 31, 1889-1891 (1999). 
22 Holland, E. A., Neff, J. C., Townsend, A. R. \& McKeown, B. Uncertainties in the temperature sensitivity of decomposition in tropical and subtropical ecosystems: Implications for models. Global Biogeochemical Cycles 14, 1137-1151 (2000).

23 Conrad, R. et al. Stable carbon isotope discrimination and microbiology of methane formation in tropical anoxic lake sediments. Biogeosciences 8, 795-814 (2011).

24 Schulz, S. \& Conrad, R. Influence of temperature on pathways to methane production in the permanently cold profundal sediment of Lake Constance. FEMS Microbiol. Ecol. 20, 1-14 (1996).

25 Nguyen, T. D., Crill, P. \& Bastviken, D. Implications of temperature and sediment characteristics on methane formation and oxidation in lake sediments. Biogeochemistry 100, 185-196 (2010).

26 Melack, J. M. et al. Regionalization of methane emissions in the Amazon Basin with microwave remote sensing. Glob. Change Biol. 10, 530-544 (2004).

27 Whittaker, R. H. Communities and Ecosystems 2nd edn (Macmillan, New York, 1975).

28 Team, R. D. C. R: A language and environment for statistical computing. (2012).

29 Marotta, H., Paiva, L. T. \& Petrucio, M. M. Changes in thermal and oxygen stratification pattern coupled to $\mathrm{CO} 2$ outgassing persistence in two oligotrophic shallow lakes of the Atlantic Tropical Forest, Southeast Brazil. Limnology 10, 195-202 (2009).

\section{Acknowledgements}

This research was supported by funds from STINT (The Swedish Foundation for International Cooperation in Research and Higher Education), The State of Rio de Janeiro Research Foundation (project E26/110.276/2012) and the Brazilian National Council of Scientific Research (project 477131/2013-1). We thank J. Johansson (Uppsala University) for sampling and chemical analysis support and R. Conrad (Max Planck Institute for Terrestrial Microbiology) for suggestions. H. Marotta is grateful for a post-doctoral fellowship from the Swedish Institute.

\section{Author Contributions}

All authors contributed to the study design, conducted the experiment, interpreted data and wrote or commented on the manuscript. H.M. and L.Q.P. also performed the sampling and most of the sample analyses.

\section{Author information}

The authors declare no competing financial interests. Correspondence and requests for materials should be addressed to H.M. 
Greenhouse gas production in low latitude lake sediments responds strongly to warming

\section{Supplementary Information}

\section{Sampling and Water and Sediment characteristics of the studied lakes}

Lakes along a gradient of dissolved organic carbon (DOC) concentration were sampled in the Amazon tropical forest $(n=9)$ and Swedish boreal forest $(n=8)$ and were selected to include a broad range of lake types in both biomes. The boreal lakes showed more DOC-enriched waters (mean $=17.6$, range $=6.0$ to $30.4 \mathrm{mg} \mathrm{L}^{-1}$ ) than the tropical lakes (mean $=3.4$, range $=0.6$ to $13.1 \mathrm{mg} \mathrm{L}^{-1}$; Table S1). The lakes in both biomes were still represented by lakes showing a similar range of nutrient concentration in the water, total P (0.02 to $\left.0.14 \mathrm{mg} \mathrm{L}^{-1}\right)$ and total $\mathrm{N}\left(0.20\right.$ to $\left.1.66 \mathrm{mg} \mathrm{L}^{-1}\right)$.

To obtain representative and comparable sediments from each lake, and given the sediment focusing to deeper sediments, we collected surface sediments at the deepest point in each ecosystem using 10 -cm deep cores. This sampling procedure was aimed to capture the most active sediment layers for anaerobic sediment organic carbon mineralisation in all lakes ${ }^{1}$. Our sediment samples encompassed a wide range of OC content (Table S1). The boreal lakes showed a significantly higher OC fraction per dry weight in the sediment (Unpaired $t$-test with Welch's correction, $\mathrm{p}<0.005, \mathrm{t}=4.42$ ) in average \pm standard error (SE) $182 \pm 26 \mathrm{~g} \mathrm{OC} \mathrm{kg} \mathrm{dry} \mathrm{sediment}^{-1}$, approximately fourfold higher than the tropical lakes (44 $\pm 16 \mathrm{~g} \mathrm{OC} \mathrm{kg} \mathrm{dry} \mathrm{sediment}^{-1}$ ). Despite the distinct OC content per dry weight in the lake sediments, or even in the lake waters, no significant differences between biomes were observed for the OC and nitrogen $(\mathrm{N})$ contents per wet weight (Unpaired $t$-test with Welch's correction, $t$-test, $\mathrm{p}>0.05$ ) or in the sediment C:N ratio. The average values across the biomes were $11 \pm 1 \mathrm{~g}$ OC $\mathrm{L}_{\text {wet sediment }}{ }^{-1}, 0.95 \pm 0.06 \mathrm{~g}$ $\mathrm{N} \mathrm{L}_{\text {wet sediment }}{ }^{-1}$ and $11 \pm 1$ (dimensionless mass unit ratio), respectively.

Water samples and sediment cores were simultaneously sampled in October 2009 by separate teams in both biomes and then handled in the same experiment in the laboratory at Uppsala University (Sweden). The sediment from the Amazon region was transported to this laboratory immediately after sampling, a maximum of 9 days prior to the beginning of the experiment. A comparison of sediment samples preserved in the field upon collection and at the start of the experiment indicated no significant OC loss over this time interval.

\section{Analytical Methods and Experimental Design}

Standard analyses were used to determine nutrient and OC concentrations in lake waters and sediments ${ }^{2}$. In the field, water temperature and $\mathrm{pH}$ were measured with calibrated probes. Water samples were frozen immediately after sampling for determination of total nitrogen and phosphorus. Samples for DOC analyses or were filtered (Whatman GF/F) and acidified to $\mathrm{pH}<2.0$ and analysed using a Sievers 900 TOC analyser. Sediment samples were analysed for density (on the basis of wet weight per volume) and water content (from the difference between dry weight and wet weight after 
lyophilisation) using a high-precision balance (Metler-Toledo precision $\pm 1 \mu$ g). The OC and $\mathrm{N}$ contents in the sediment were determined using a CHN analyser (Costech) after $\mathrm{HCl}$ acidification ${ }^{2}$. Headspace gas samples for $\mathrm{CO}_{2}$ and $\mathrm{CH}_{4}$ analyses were performed using a 6890A Agilent gas chromatograph equipped with TCD and FID detectors and a nickel catalyst methanizer ${ }^{3}$.

The experiment was performed with water and sediment samples incubated in 25-ml glass vials hermetically sealed with a 10 -mm-thick massive butyl rubber stopper (Apodan, Denmark) secured with an aluminium crimp seal. These glass vials were previously washed and the rubber stoppers boiled at least 5 times to extract possible water-soluble substances. The water and sediment samples were homogenised separately and purged with $\mathrm{N}_{2}$ to reach anoxic conditions. Each vial was then filled with $5 \mathrm{ml}$ sediment and $5 \mathrm{ml}$ lake water while the remaining headspace was purged with $\mathrm{N}_{2}$ gas. Vials were close sealed to avoid any oxygenation. The sample vials were placed inside 6 boxes filled with water under different controlled temperatures. When the samples were removed, biological activity was stopped by acidification to $\mathrm{pH}<1.5$ after adding $2 \mathrm{ml}$ of $10 \%$ sulphuric acid to each vial. In total, we used 2516 sample vials over the experiment for the 17 lakes, 6 temperatures $\left(4.3,10.0,13.7,19.3,29.1,40.5^{\circ} \mathrm{C}\right), 7$ experimental times $(0,3,6,10,20$, 30 , and 44 days after controlled-temperature incubations) and 4 replicate vials per time, temperature and lake.

\section{Statistical analyses and upscaling}

The effect of temperature on the anaerobic OC mineralisation was assessed in two steps. First, the maximum slope of the linear regression of $\mathrm{CO}_{2}-\mathrm{C}, \mathrm{CH}_{4}-\mathrm{C}$ or $\mathrm{CO}_{2 \text { eq }}$ concentrations vs. the incubation time, from at least three consecutive sampling times over 44 days $(P<0.05, n=4$ replicates per sampling time), was used as a measure of the $C$ gas production rate at each temperature. This procedure yields a potential rate to avoid the comparison problems resulting from different time lags among lakes and temperatures. All data regarding the rate of $\mathrm{CO}_{2}$ and $\mathrm{CH}_{4}$ and $\mathrm{CO}_{2 \text { eq }}$ production, were $\log _{10}$-transformed in order to achieve normal distribution, stabilize the variance and linearize the exponential response.

The response to temperature for each lake and variable was assessed by means of ordinary least square (OLS) regression as well as robust regression. We used nonparametric density estimation function and Shapiro-Wilk test to assess the normality; Levene's test, for homogeneity of variance. In order to minimize the effect of influential observations and outliers on the regression coefficients, we used robust regression analysis with M-bisquare and MM-estimation. The plot of residuals from the OLS fit against the residuals from the robust regression solution was used to check for outliers. The comparison of slopes and intercepts included regression coefficients that were derived from OLS as well as robust regressions. We also compared slopes and intercepts derived from OLS regression without taking into account outliers and influential observations.

The linear regressions of $\log _{10}$-transformed $\mathrm{CH}_{4}, \mathrm{CO}_{2}$ and $\mathrm{CO}_{2 \text { eq }}$ production vs. temperature, were eventually used to generate a pooled dataset for tropical and boreal 
lakes (see Figure 1). The linear regressions of pooled log10-transformed data for each of the $\mathrm{CH}_{4}, \mathrm{CO}_{2}$ and $\mathrm{CO}_{2}$ eq production vs. temperature (Table 1) were used to compare and predict the mean biome level response to temperature. The assumptions of normality, homogeneity of variance and linearity were checked and their coefficients were similar whether estimated by OLS or by different robust regression estimations.

The predicted mean temperature response of anaerobic $\mathrm{CH}_{4}, \mathrm{CO}_{2}$ and $\mathrm{CO}_{2 \text { eq }}$ production in tropical and boreal lakes, were corrected for the back-transformation bias of $\log _{10}$-transformed data ${ }^{4}$. Based on the relationships in Table 1 , we also calculated the increases in sediment anaerobic OC mineralisation for each biome for the predicted IPCC warming B1 scenario. We assumed conservative estimates for current mean temperatures at the sediment surface: $4^{\circ} \mathrm{C}$ for boreal lakes (selected to be higher than the previously suggested $1{ }^{\circ} \mathrm{C}^{5}$ to yield conservative results), and $26^{\circ} \mathrm{C}$ for Amazon lakes, following the 30-year mean air temperature of these tropical ecosystems (Brazilian Institute of Meteorology, INMET, available at www.inmet.gov.br), as shallow depths predominate in this region ${ }^{6}$. We then used the more conservative IPCC prediction for regional warming projected to 2100 (B1 scenario), which was simulated by multi-model datasets incorporating predicted temperature changes in Amazonia $\left(1.6-4.2^{\circ} \mathrm{C}\right)$ and Sweden $(1.8-$ $\left.4.5^{\circ} \mathrm{C}\right)^{7}$ to estimate subsequent increase rates in anaerobic OC mineralisation from $\mathrm{CO}_{2}$ $\mathrm{CH}_{4}$ and $\mathrm{CO}_{2 \text { eq }}$ production in the sediments.

Assuming that the majority of lakes in the Boreal zone are dimictic, and thereby stratified with the deep hypolimnetic water layers being disconnected from air temperatures, the epilimnetic sediment area is of interest because it will closely follow atmospheric temperatures ${ }^{8}$. In a previous publication ${ }^{5}$, we estimated that approximately $42.5 \%$ of the sediment area in Boreal lakes is covered by epilimnetic waters. Thus the prediction about future increase in anaerobic GHG production is limited to this zone in boreal lakes.

In tropical lakes on the other hand, never experiencing extended periods with air temperatures below $4{ }^{\circ} \mathrm{C}$, there is less difference between surface and bottom water temperatures in stratified water bodies, and the bottom water temperature will reflect the air temperatures during the time when stratification settled. Therefore, bottom water temperatures in tropical lakes are over time sensitive to increased air temperatures. While the deep tropical lakes tend to be oligomictic, the shallower lakes (about $0-10 \mathrm{~m}$ ) are typically discontinuously polymictic or polymictic with complete daily mixing (with only a few degrees difference it does not take much energy to mix the water) ${ }^{6}$. The two latter categories are a major share of the tropical lakes, including the numerous floodplain lakes. In deep water bodies in river systems, as well as by seasonal large changes of water levels, hydrological mixing can be influential resulting in well mixed systems with water temperatures similar to air temperatures - again much less energy is required to mix tropical compared to boreal water bodies. Therefore the temperature throughout the water columns of both deep and shallow tropical water bodies will respond to climate change and the whole lake area could be used in the extrapolation.

The extrapolation to boreal and tropical lake sediments using equations in Table 1 is based on the assumption that the studied lakes represent the general temperature 
sensitivity of sediment mineralization in the lakes in these regions. The absence of significant differences between the biomes for $\mathrm{CO}_{2}$ and $\mathrm{CH}_{4}$ in our dataset indicates that data represents the variability that can be expected for lakes in different regions. To test for sensitivity of $\mathrm{CO}_{2 \text { eq }}$ production to the variability in slopes and intercepts among lakes we repeated the upscaling with equations using the $25 \%$ and $75 \%$ quartiles of slopes and intercepts from the tropical and boreal lakes separately. All combinations of quartiles for both slopes and intercepts were tested. The most conservative case was combining the $25 \%$ quartiles for tropical lakes (representing lakes with lower temperature sensitivity than average for the tropical lakes) with the $75 \%$ quartiles for the boreal lakes (higher temperature sensitivity than average). Still the $\mathrm{CO}_{2 \text { eq }}$ production in tropical sediments ranged from 2.4 to 4.5 times that in boreal sediments indicating that the result of stronger feedbacks in the tropics is robust.

The upscaling calculations included the top 10 -cm sediment layer, using the wet sediment densities of $1.29 \pm 0.07$ and $1.01 \pm 0.01$ and $\mathrm{kg} \mathrm{L}^{-1}$ (average $\pm \mathrm{SE}$ ) for the tropical and boreal lakes analysed here, respectively. To upscale the sediment anaerobic mineralization rates, we used an area of tropical lakes (between $23^{\circ} \mathrm{S}$ and $23^{\circ} \mathrm{N}$ ) of $391,686 \mathrm{~km}^{2}{ }^{(9)}$, derived from the latitudinal distribution of lake $\mathrm{area}^{3}$, and an area of boreal lakes of $1.25 \times 10^{6} \mathrm{~km}^{2(10)}$. 


\section{References}

1 Thebrath, B., Rothfuss, F., Whiticar, M. J. \& Conrad, R. Methane production in littoral sediment of Lake Constance. FEMS Microbiol. Ecol. 102, 279-289 (1993).

2 APHA. Standard methods for the examination of water and wastewater. 18 edn, Vol. (American Public Health Association, 1992).

3 Bastviken, D. et al. Methane Emissions from Pantanal, South America, during the Low Water Season: Toward More Comprehensive Sampling. Environ. Sci. Technol. 44, 5450-5455 (2010).

4 Newman, M. C. Regression analysis of log-transformed data: Statistical bias and its correction. Environmental Toxicology and Chemistry 12, 1129-1133 (1993).

5 Gudasz, C. et al. Temperature-controlled organic carbon mineralization in lake sediments. Nature 466, 478-483 (2010).

6 Lewis, W.M.Jr. Tropical lakes: how latitude makes a difference. In. Schiemer F. and Boland K. T. (eds) Perspectives in Tropical Limnology, SPB Academic Publishing. Amsterdam (1996).

7. Solomon, S. et al. Contribution of Working Group I to the Fourth Assessment Report of the Intergovernmental Panel on Climate Change. (Cambridge University Press, Cambridge, United Kingdom, 2007).

8 Cyr, H. Temperature variability in shallow littoral sediments of Lake Opeongo (Canada). Freshwater Science 31, 895-907 (2012).

9 Lehner, B. \& Doll, P. Development and validation of a global database of lakes, reservoirs and wetlands. J. Hydrol. 296, 1-22 (2004).

10 Molot, L. A. \& Dillon, P. J. Storage of terrestrial carbon in boreal lake sediments and evasion to the atmosphere. Global Biogeochemical Cycles 10, 483-492 (1996). 
Supplementary Table S1: Geographic coordinates, area (ha), sampling depth (m) conductivity $\left(\mu \mathrm{S} \mathrm{cm}{ }^{-1}\right)$, temperature $\left({ }^{\circ} \mathrm{C}\right), \mathrm{pH}$ (dimensionless), Total $\mathrm{N}\left(\mathrm{mgL}^{-1}\right)$, Total $\mathrm{P}\left(\mathrm{mgL}^{-1}\right)$ and DOC $\left(\mathrm{mgL}^{-1}\right)$ in waters, and Wet Sediment Density $\left(\mathrm{g} \mathrm{mL}^{-1}\right)$, OC-content $\left(\mathrm{g} \mathrm{kg}^{-1}\right)$, N-content $\left(\mathrm{g} \mathrm{kg}^{-1}\right)$ and $\mathrm{C}: \mathrm{N}$ ratio (\% weight basis) in the wet sediment used in the experiment. AM and $\mathrm{BO}$ denote Amazon and boreal lakes, respectively.

\begin{tabular}{|c|c|c|c|c|c|c|c|c|c|c|c|c|c|c|}
\hline \multirow{2}{*}{$\begin{array}{c}\text { Lak } \\
\text { es }\end{array}$} & \multicolumn{2}{|c|}{ Geographic } & \multirow[b]{2}{*}{$\mathrm{Ar}$} & \multirow[b]{2}{*}{ Dep } & \multirow[b]{2}{*}{ Con } & \multicolumn{4}{|c|}{ Bottom Lake Waters } & \multirow[b]{2}{*}{ DO } & \multicolumn{4}{|c|}{ 10-cm Surface Layer of } \\
\hline & Latitud & Longit & & & & Tem & $\mathrm{p}$ & Tot & Tot & & Wet & C- & $\mathrm{N}-$ & C: \\
\hline $\mathrm{AM}$ & $02^{\circ} 26^{\prime}$ & $54^{\circ} 46^{\prime}$ & 59 & 1 & 9.6 & 30.3 & 6. & 76 & 11 & 1.3 & 1.30 & 10.1 & 8 & 12. \\
\hline $\mathrm{AM}$ & $02^{\circ} 31^{\prime}$ & $54^{\circ} 29^{\prime}$ & 10 & 0.8 & 192 & 36.0 & 6. & 0.98 & 0.06 & 13. & 1.43 & 5.0 & 0.5 & 10. \\
\hline $\mathrm{AM}$ & $02^{\circ} 31^{\prime}$ & $54^{\circ} 25^{\prime}$ & 0.3 & 0.6 & 65 & 33.0 & 8. & 1.66 & 0.05 & 6.6 & 44 & 4.5 & .5 & 9.0 \\
\hline $\mathrm{AM}$ & $02^{\circ} 27^{\prime}$ & $54^{\circ} 05^{\prime}$ & 2 & 1.5 & 21 & 30.0 & 4. & .47 & 0.06 & 1.4 & .15 & 10.4 & 1.0 & 13. \\
\hline $\mathrm{AM}$ & $02^{\circ} 28^{\prime}$ & $54^{\circ} 06^{\prime}$ & 3 & 0.9 & 9 & 33.0 & 5. & 2 & 0.04 & 2.1 & 5 & 19.0 & 2 & 16. \\
\hline $\mathrm{AM}$ & $02^{\circ} 29^{\prime}$ & $54^{\circ} 05^{\prime}$ & 0.2 & 0.6 & 21 & 34.0 & 5. & 1.49 & 0.13 & 1.8 & 1.11 & 13 & 1.1 & 12. \\
\hline $\mathrm{AM}$ & $02^{\circ} 25^{\prime}$ & $54^{\circ} 16^{\prime}$ & 1 & 2.5 & 48 & 31.7 & 7. & 0.97 & 0.14 & 2.9 & 1.61 & 4.0 & 0.6 & 10. \\
\hline $\mathrm{AM}$ & $02^{\circ} 26^{\prime}$ & $54^{\circ} 54^{\prime}$ & 17 & 2 & 5 & 30.3 & 4. & 0.25 & 0.02 & 0.6 & 2 & 12 & 0.9 & 13. \\
\hline $\mathrm{AM}$ & $02^{\circ} 30^{\prime}$ & $54^{\circ} 57^{\prime}$ & 63 & 1.7 & 9 & 29.6 & 6. & 0.46 & 0.02 & 1.0 & 1.53 & & 0.5 & 10. \\
\hline $\mathrm{BO}$ & $60^{\circ} 20^{\prime}$ & $17^{\circ} 45^{\prime}$ & 20 & 2.8 & 83 & 3.9 & 7. & 1.16 & 0.02 & 30. & 0.99 & 16 & 1.2 & 13. \\
\hline $\mathrm{BO}$ & $59^{\circ} 53^{\prime}$ & $17^{\circ} 57^{\prime}$ & 83 & 4.3 & 287 & 3.5 & 7. & 1.66 & 0.05 & 26. & 1.05 & 11.4 & 1.2 & 9.9 \\
\hline $\mathrm{BO}$ & $59^{\circ} 52^{\prime}$ & $17^{\circ} 56^{\prime}$ & 63 & 10.2 & 230 & 4.4 & 7. & 0.81 & 0.04 & 10. & 1.01 & 9.3 & 1.1 & 8.8 \\
\hline $\mathrm{BO}$ & $59^{\circ} 52^{\prime}$ & $17^{\circ} 10^{\prime}$ & 13 & 2.8 & 166 & 18 & 7. & 0.9 & 0.04 & 16. & 1 & 10 & 1.2 & 8.8 \\
\hline $\mathrm{BO}$ & $59^{\circ} 52^{\prime}$ & $15^{\circ} 11^{\prime}$ & 7 & 10.3 & 30 & 2.7 & 5. & 0.02 & 0.01 & 14. & 1.00 & 14 & 0.9 & 16. \\
\hline $\mathrm{BO}$ & $59^{\circ} 53^{\prime}$ & $15^{\circ} 15^{\prime}$ & 0.7 & 6.1 & 50 & 2.5 & 4. & 0.78 & 0.02 & 17. & 1.04 & 16.0 & 0.8 & 19. \\
\hline $\mathrm{BO}$ & $59^{\circ} 54^{\prime}$ & $15^{\circ} 23^{\prime}$ & 24 & 20 & 53 & 3.2 & 6. & 0.20 & 0.01 & 6.0 & 1.00 & 13.9 & 0.9 & 15. \\
\hline $\mathrm{BO}$ & $59^{\circ} 56^{\prime}$ & $15^{\circ} 24^{\prime}$ & 3 & 5 & 26 & 2.2 & 5. & 0.84 & 0.02 & 19. & 0.95 & 13.4 & 0.9 & 15. \\
\hline
\end{tabular}



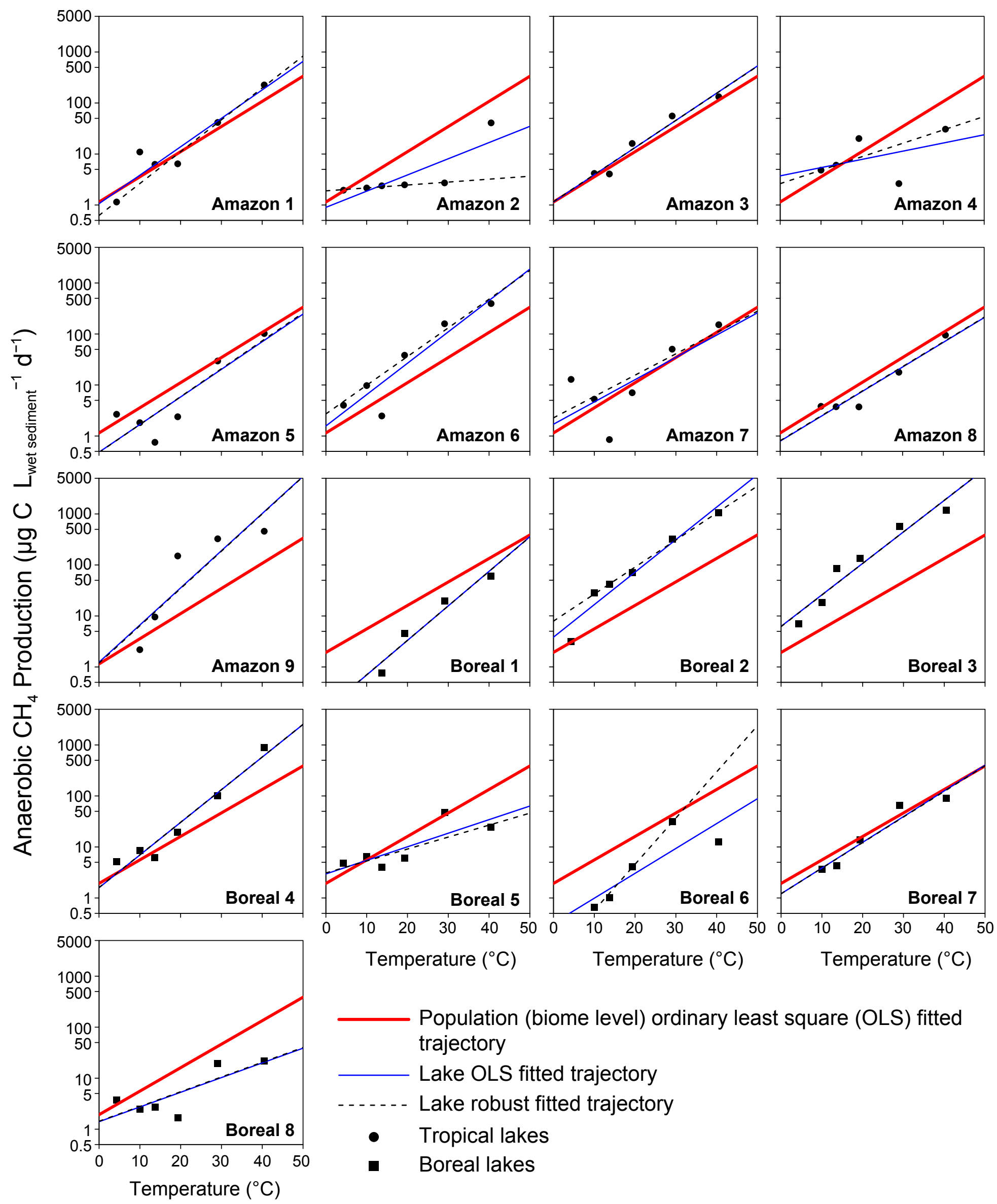

Temperature $\left({ }^{\circ} \mathrm{C}\right)$

Temperature $\left({ }^{\circ} \mathrm{C}\right)$

Temperature $\left({ }^{\circ} \mathrm{C}\right)$

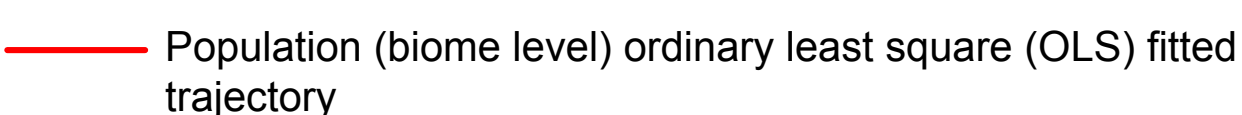
trajectory

Lake OLS fitted trajectory

...... Lake robust fitted trajectory

- Tropical lakes

- Boreal lakes

Supplementary Figure $\mathrm{S} 1$. Temperature dependence of the anaerobic $\mathrm{CH}_{4}$ production in the sediments of the studied lakes. The $y$-axis is represented on a log-scale. 

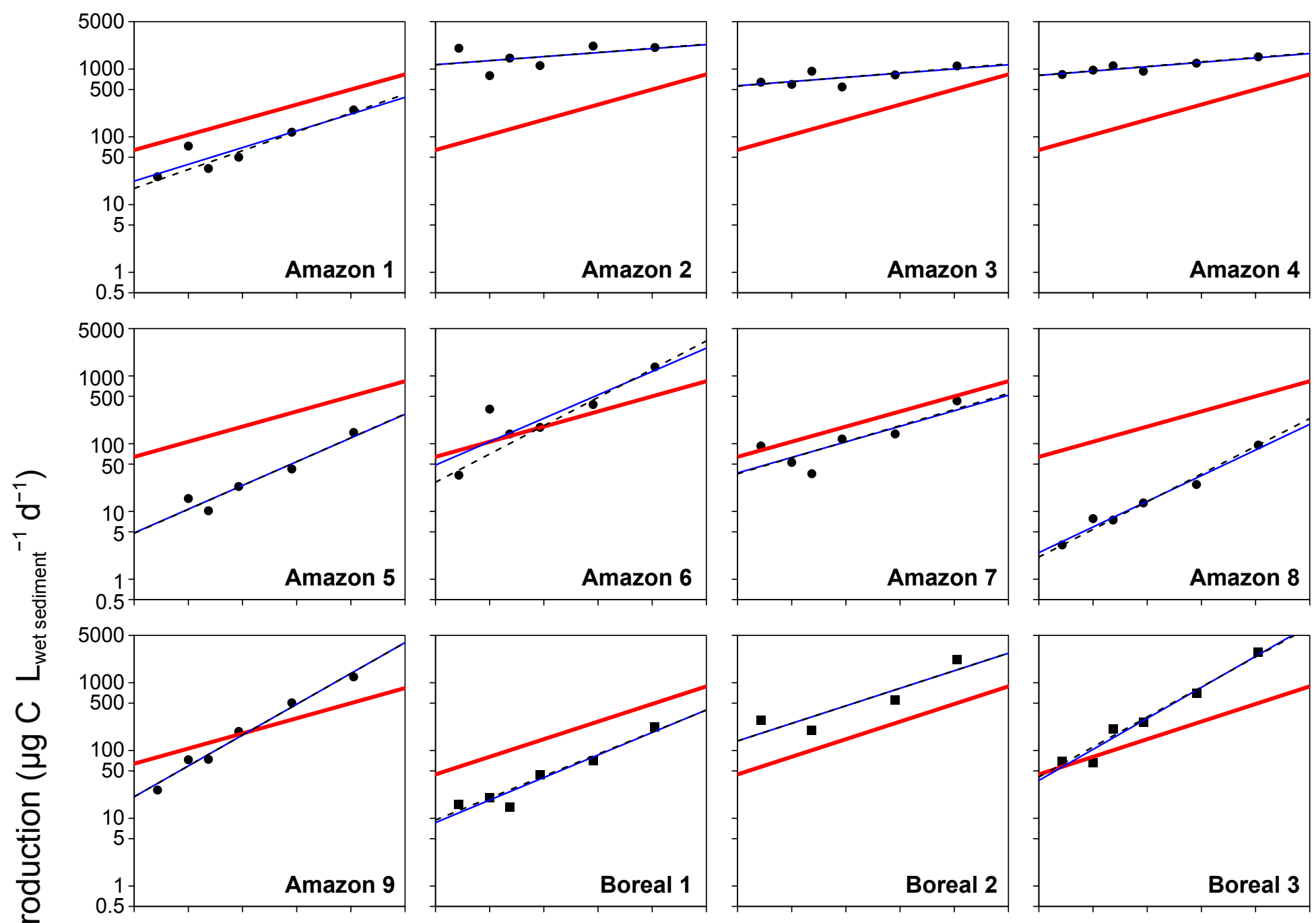

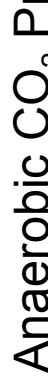
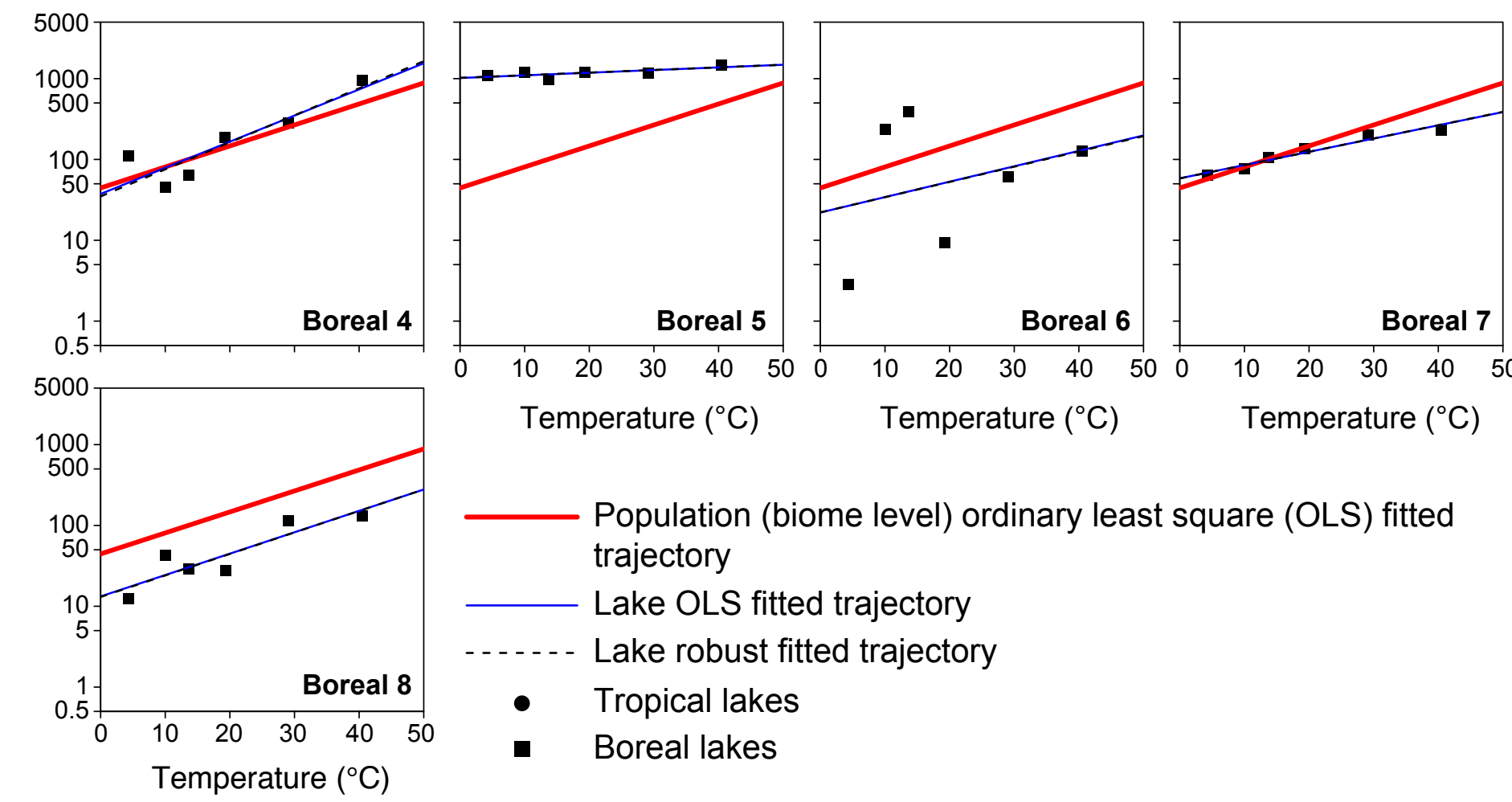

Supplementary Figure S2. Temperature dependence of the anaerobic $\mathrm{CO}_{2}$ production in the sediments of the studied lakes. The $y$-axis is represented on a log-scale. 